\title{
Review of Cancer-Testis (CT) Genes
}

\author{
Mi-Hee Kim ${ }^{\dagger}$, Myung-Ha Song ${ }^{\dagger}$ and Sang-Yull Lee*
}

Department of Biochemistry, School of Medicine, Pusan national University, Yangsan 626-870, Korea

Received May 19, 2011 / Accepted June 20, 2011

\begin{abstract}
Cancer-testis (CT) antigens are immunogenic protein antigens with restricted expression in the testes and a wide range of human tumor types, eliciting both humoral and cellular immune responses in cancer patients. They are considered to be ideal targets for vaccine-based immunotherapy, and more than 100 CT antigens, including MAGE, NY-ESO-1, GAGE, BAGE, LAGE, SSX2 and NY-SAR-35 have been identified to date. The CT antigens were identified through various techniques and can be divided in those that are encoded on the $X$ chromosome, the CT-X genes, and those that are not, the non-X-CT genes. CT genes are aberrantly activated and expressed in a proportion of various types of human cancers. The biological role of CT-X in both germ line tissues and tumors remains poorly understood. Cancer vaccine trials based on several CT antigens are currently ongoing. This paper reviews recent advances in and future trends of $\mathrm{CT}$ antigens for cancer immunotherapy.
\end{abstract}

Key words : Cancer-testis gene, cancer vaccine, immunotherapy, SEREX

\section{서 론}

지난 100년 동안 암에 대한 인간 면역 시스템의 강력한 세포 사멸 능력과 관계된 암 항원을 찾기 위한 연구가 계속해서 있어왔다. 면역치료를 위한 이상적인 암 항원은 정상 조직에 서는 발현되지 않고 특이적이고 안정하게 암에서 발현되며 암세포의 생존에 중요한 역할을 하는 것이다. 이 연구에서 중 요한 관점은 Autologous typing이라 불리는 접근법의 적용이 다. 이 접근법은 환자로부터 분리 후 배양된 암세포와 정상세 포가 환자 자신의 항체와 $\mathrm{T}$ cell에 의해 특이적 면역 인식에 대한 target으로 사용되어진다. 최초의 cancer-testis (CT) antigen은 새롭게 개발된 DNA-cloning methodology (T cell에 의 해 인식된 target을 규명하기 위한 방법)를 통해 발견되었다 $[40,41]$. 멜라노마 환자에서 autologous tumor cells을 인식하 는 cytotoxic T cell을 가지는 것을 확인하였다. 이 시스템을 이용하여 tumor antigen MZ2-E을 암호화하는 유전자가 클로 닝되었다. 그 유전자는 MAGE1이고 MAGE2 유전자와 매우 밀접한 관련이 있었다. 뿐만 아니라 MAGE3이 같은 cell line 에서 연속적으로 확인되었다[11]. MAGE1 유전자의 발현은 멜라노마, 유방암 그리고 다른 여러 종류의 암 조직에서 발견 되었다[39]. 하지만 고환을 제외한 정상조직에서는 발현되지 않는다. 추가 분석에서 MAGE family와 밀접한 관계를 가지는 12 개의 유전자가 알려졌고 Xq28에 위치하였다. sex-reversal phenotype에 관한 유전자에 관한 연구 중 MAGE 유전자의 두 번째 유전자 군집을 밝혔고 그것들은 MAGEB 유전자를

† Mi-Hee Kim and Myung-Ha Song contributed equally to this work.

*Corresponding author

Tel : +82-51-510-8080, Fax : +82-51-510-8086

E-mail : sangyull@pusan.ac.kr
암호화 하고 있었으며 Xp21.3에 위치하고 있었다. 계속해서 MAGEC 유전자를 암호화 하는 세 번째 유전자 군집이 확인되 었고, 그것의 위치는 Xq26-27에 있었다. 이들 가족성 유전자는 고환 또는 암조직에 제한적으로 발현되었다. 이에 비교하여 MAGED에서 MAGEL유전자는 앞의 MAGE 유전자들과 밀접 성이 떨어지고 많은 정상 조직에서 발현됨을 확인하였다[8]. MAGEA1이 발견된 같은 환자로부터 cytotoxic T cell을 이용 하여 B melanoma antigen (BAGE) and G antigen 1 (GAGE1) 을 발견하였다[3]. 이 유전자들은 MAGE 유전자와 유사성을 띄지는 않는다. 하지만 고환과 악성 종양에서만 발현되는 점 은 비슷하였다.

암 항원을 찾기 위한 그 다음 중요한 단계는 항체를 이용하 여 cDNA expression libraries의 screening 방법이다[32,33]. 이 기술은 SEREX라고 불리는 것으로 여러 가지 카테고리의 암 항원을 확인할 수 있는 방법이다(Fig. 1). 이 방법은 Ludwig Institute for Cancer Research의 주도하에 다양한 암 형태에 적용되었고 많은 그룹의 연구자들의 노력으로 1,000 개 이상의 암 항원의 발견을 이루었다(http://ludwig-sun5.unil.ch/ CancerImmunomeDB/; http://www.cancerim munity.org/ $\mathrm{SEREX} /$ ). 암 항원의 카테고리에는 성인 조직에서 주로 발견 되는 돌연변이 형태나 과 발현 형태의 유전자 생산물이 이에 속하고 뿐만 아니라 성인 정상 조직에서는 발현되지 않으나 암 조직에서는 활성화되는 유전자도 이에 속한다. 특히 후자 는 SSX, SCP1, NY-ESO-1, 그리고 NY-SAR-35 등 여러 가지 testis-restricted antigen을 포함하고 있다[5,6,19]. 암에서 발현 되는 testis genes의 목록이 점점 늘어가는 가운데 이 카테고리 에 관한 명명이 필요하였고 Old 와 Chen 박사 그룹에서 CT antigen으로 명명하였다[28]. 그리고 그 후 연구에서 CT antigen은 고환의 생식 세포 계열에서만 제한적으로 발현되는 것 
이고, 뿐만 아니라 태아 난소의 미성숙 생식 세포 내 영양막 세포에서도 발현된다[6].

MAGEA와 NY-ESO-1은 종양에 대한 T-cell의 반응을 자극 하며 강력한 암 백신으로 연구되고 있다[15,23]. 이들 항원 중 한 가지 또는 그 외 다른 것을 포함하는 백신은 세포성 그리고 체액성 반응을 유도하는 것이다. 치료받은 환자들의 일부가 예방접종의 임상적 장점을 잘 보여주고 있다. 백신 표적으로 $\mathrm{CT}$ antigen은 자세히 연구되었고 그들은 넓은 범위의 암 조직 에서 발현되었다. 추가적으로 가능성 있는 백신 표적을 확인 하기 위하여 암에서 재발현 되는 것으로 알려진 germ-line 유 전자에 대하여 전략적인 탐색이 있었다. 이것은 이미 RT-PCR 후 PCR로 확인 작업을 거친 expressed sequence tag (EST) data를 사용하여 이뤄졌다. 비록 transcriptional data가 tumor antigen을 암호화 하는 유전자를 명시하고 있지는 않지만 암 과 germ-line에서 모두 발현되는 유전자 산물을 현재 CT antigen으로 간주하고 있다. CT antigen의 현재 카탈로그는 100 개 의 다른 CT antigen family 유전자를 포함하고 있다. 그들 중 에는 다중 구성원을 가지는 MAGEA와 GAGE1과 같은 것이 있고 XAGE1a와 XAGE1b와 같은 스플라이스 변이체도 있다. 이 스플라이스 변이체는 89가지 전사체를 만들어낸다. CT antigen이 되기 위한 단백질은 반드시 고환 또는 태반뿐만 아니 라 종양에서 발현되어야 한다. 하지만 두 가지 이상 비생식 계열의 정상 세포에서는 발현되지 않는다. 비생식 계열의 정 상 세포 발현이 발견될 때 이것은 단지 고환에서 발현되는 수준의 일부분에 그친다. 생식세포의 발달과 분화에 중요한
역할을 하는 많은 다른 유전자들이 체조직에서 발현된다. 알 려진 CT antigen이 존재할 때 활성화되는 유전자들은 암에서 germ-line 유전자의 발현에 관한 앞으로의 연구에 중요한 요 소가 될 것이다[35].

본 논문은 CT antigen 유전자의 특징, 분류, 생물학적 기능 및 암 면역 백신 응용에 대하여 고찰 할 것이다.

\section{CT antigen이란?}

$\mathrm{CT}$ antigens은 정상 고환과 여러 다른 종양에서 발현되는 종양 항원의 일종이다. 그들의 이름에서 암시하듯 그들의 발 현은 고환의 생식 세포에서 나타난다. 하지만 때때로 그들은 여성의 생식 기관과 영양막 세포에서도 발현된다. 태아 난소 의 미성숙 생식 세포(oogonia과 primary oocyte)는 cancer-testis antigen을 발현하지만 그들의 발현은 primordial follicle을 만드는 oocyte에서는 보이지 않는다. 태반의 세포 영양막과 융합세포 영양막은 일부 CT antigen을 발현한다. 태반에서 이 항원의 발현은 다른 항원의 발현과는 다르다. 그것은 그들 중 일부는 태반에서 발현되지 않으나 일부는 매우 높게 발현되 고, 그들의 발현은 태아 생식 세포에서와 비교 시 완벽히 동등 하게 나타나지는 않는다[16].

악성 조직과 영양막 세포는 침윤성, 파괴성, 전이성의 특징 을 공유하기 때문에 태반의 유전자들의 발현 양상은 암에서와 비슷하다. 어떤 $\mathrm{CT}$ antigen은 nongametogenic tissue (췌장, 간, 비장)에서 germ cell보다 낮은 수준에서 발현될 수 있다.
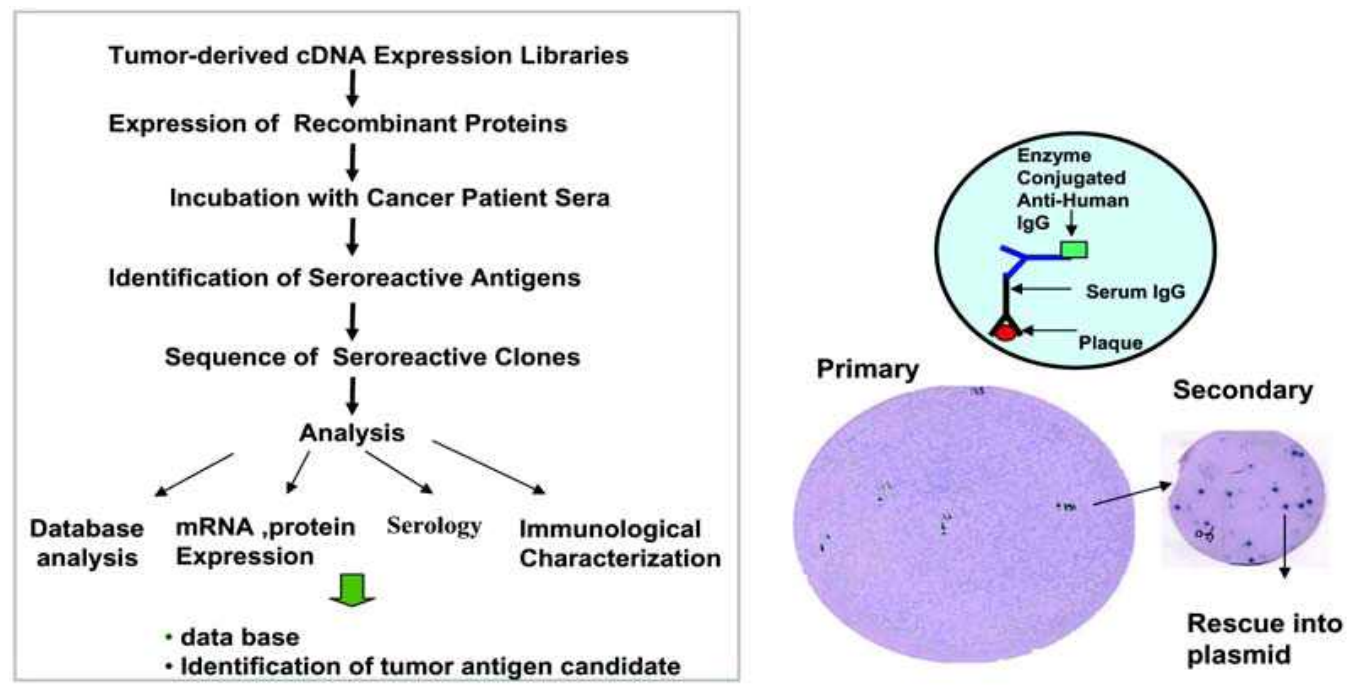

Fig. 1. Method of SEREX for discovery of tumor antigen CDNA expression libraries are made from tumor tissues, tumor cell lies, or testis tissues. The obtained cDNA library is cloned into $\lambda$ ZAP expression vector. cDNA expression libraries are screened with pooled sera of patients with cancers. Immune reactive clones are selected by reacting nitrocellulose membrane containing recombinant clones with pooled sera of patients with cancers followed by incubation with alkaline phosphatase-conjugated secondary antibody. Thus selected clones are subjected to in vivo excision and sequencing to determine identity of each immune reactive clone. 
게다가 최근 어떤 CT antigen (N-RAGE, NY-ESO-1, MAGE, and SSX)은 성인과 태아 모두 골수 내 중간엽 줄기세포에서 발현된다. 하지만 osteocyte와 adipocytes로 분화된 이후 그들 의 발현 정도는 저하된다. 그것은 CT antigen의 발현이 gametogenesis의 특징이 될 뿐만 아니라 stem cell marker가 될 수 있다는 가능성을 남긴다. 분화되지 않은 체액성 세포와 줄기 세포에서 이 항원의 제한된 발현은 embryonic development 에 필수적인 역할이 있음을 제안한다. CT antigens은 그들의 고도의 조직 제한적 발현 때문에 암 백신을 위한 표적 분자로 생각되고 있다. 현재 다양한 종양에서 적어도 100 개의 CT antigen 유전자들의 발현에 대한 연구가 진행되고 있다[12,24].

\section{CT antigens의 동정}

CT antigens을 확인하기 위해서 여러 가지 방법들이 사용 된다.

\section{T cell epitope cloning}

$\mathrm{CD} 8+\mathrm{T}$ cells에 의해 인식되는 많은 항원이 암세포로 구성 된 recombinant cDNA library을 표적세포로 형질도입하여 밝 혀지고 있다. 이 방법은 표적세포의 표면에 적합한 HLA 분자 를 발현시키고 그 다음 암 침윤물로부터 분리된 antitumor $\mathrm{T}$ cells을 사용하여 표적세포 표면의 에피토프를 확인한다. 이 기술로 첫 번째 클로닝된 항원은 멜라노마 항원 MAGE-1이다. $B$ melanoma antigen (BAGE)와 $\mathrm{G}$ antigen (GAGE) gene family를 포함하는 다른 새로운 암 항원이 이 기술에 의해 확인되 었다 $[3,40,41]$

Serological analysis of CDNA expression libraries
(SEREX)

세포성과 체액성 면역 시스템 모두 종양 항원의 인지에 관 여한다. Sahin과 그의 학생들은 이를 이용하여 새로운 방법을 개발하였다. 그것은 항원의 확인을 위해 암환자의 항체 레퍼 토리를 사용하는 방법이다(Fig. 1).

SEREX 접근법은 다음과 같은 특징을 가진다. 첫 번째 in vivo에서 암세포에 의해 발현되는 유전자를 분석하기 위해서 신선한 암 조직 표본을 사용해야 한다. 두 번째 환자 혈청의 사용으로 여러 항원을 확인할 수 있다. 세 번째 스크리닝은 높은 역가의 항체반응을 나타내는 항원에 제한적이다.

SEREX는 암조직, 암세포 계열, 고환조직으로 준비된 박테 리아파지 재조합 cDNA expression library를 사용한다. SEREX 분석을 위하여 암세포를 사용하는 것은 암조직 표본에 서 정상세포의 오염이 있을 수 있는 점을 방지하고 위양성 IgG expression clone을 일으키는 B cells을 제거할 수 있다는 장점이 있다. cDNA exoression library는 E. coli에 형질도입 된다. 그 다음 재조합 단백질 라이브러리가 만들어지고 이것
은 다시 nitrocellulose membrane으로 옮겨진다. 이 membrane을 희석된 암환자의 혈청에 배양시킨다. 높은 역가의 항 체와 반응하는 클론을 효소를 이용하여 확인한다. 양성 클론 은 DNA 염기서열분석으로 이어진다. 삽입된 DNA의 염기서 열 정보는 전사체의 발현 프로필을 결정하기 위해 사용되고 또, 각 항원에 대한 항체의 반응을 평가하기 위해 사용된다. SEREX는 고형암, 자가면역질환을 가진 환자에서 항원을 확인 하기 위해 광범위하게 사용되고 있다 [18]. 이 방법을 이용하여 밝혀진 CT antigens에는 NY-ESO-1, CT7/MAGE-C1, SCP-1, OY-TES-1, HOM-TES-85, CAGE, cTAGE, and NY-SAR-35 등 이 있다[4].

\section{Differential gene expression analysis}

Differential display는 두 가지 또는 그 이상의 mRNA 사이 에 유전자 발현을 비교하기 위해 사용되는 강력한 도구이다. 이 기술의 첫 번째는 조직의 DNA fingerprints를 제공하기 위해 PCR과 denaturing polyacrylamide gel electrophoresis 를 시행하는 것이다. 비교할 시료로부터 RNAs를 추출하고 그 것은 다시 역전사된다. 그리고 $\mathrm{cDNA}$ 혼합물은 전기영동에 의해 분리된다. CT antigen은 고환과 암조직 라이브러리의 비 교를 통해 효과적으로 확인할 수 있다[13].

\section{Massively parallel signature sequencing (MPSS)}

이 접근법에서는 서로 다른 RNA 전사체로부터 수많은 짧 은 염기서열의 $\operatorname{tag}$ 이 발생하고 정상 고환과 다른 여러 암조직 의 MPSS data가 비교된다. 이 접근법을 사용하면서 CT45라 불리는 새로운 $\mathrm{CT}$ antigen gene이 발견되었다. 이것은 종종 폐암에서 발현된다[7].

\section{DNA microarrays}

Microarrays는 고형 지지대에 수 천 개의 유전자 서열의 probe가 존재한다. 방사성, 형광물질 또는 화학발광체를 이용 하여 표지된 cDNA 표적이 array의 유전자 서열과 하이브리드 화 된다. 그리고 각각의 반응된 probe에 의해 발생된 신호 강 도가 반응의 정도를 암시한다. 이 기술을 사용하면서 종양 샘 플들 사이의 유전자 풀에서 고환 특이적 항원에서 유래된 DNA 서열을 비교할 수 있게 되었다. 이 방법을 이용하여 새로 운 CT antigen이 확인되었고, 그 이름은 STK31이며 colorectal cancer에서 확인하였다[43].

\section{Tissue microarray}

Tissue microarray technology 은 한 번의 실험에서 수 백 개의 조직을 동시에 분석할 수 있는 강력한 도구이다. 이 방법 은 단백질 발현에 대한 면역조직화학방법과 FISH (fluorescence in situ hybridization)와 같은 다양한 방법들에 의존적이다. 이 방법의 장점은 한 실험 당 수많은 샘플로 하나의 유전자를 
실험할 수 있다는 것이다. 따라서 다양한 암조직의 샘플로 하 나의 고환 유전자의 발현에 관한 실험을 할 수 있다[22].

\section{Serial analysis of gene expression (SAGE)}

Serial analysis of gene expression (SAGE)는 많은 수의 전 사체를 정량하고 비교할 수 있는 방법이다. $\mathrm{cDNA}$ 전사체의 한 부분인 SAGE $\operatorname{tag}$ 만이 각 특정 조직의 발현 프로파일 분석 을 위해 필요하다. 첫 번째로 SAGE tag의 concatemers (반복된 염기서열로 구성된 DNA 입자)가 만들어지고 그 다음 30개 정 도의 tag이 한 번에 염기서열분석이 이뤼진다. Concatenated sequence 내 각각 tag의 빈도는 그 세포에서 해당 전사체의 양을 보여준다.

SAGE libraries는 세포나 조직 사이 유전자 발현의 차이를 분석하는데 이용될 수 있다[12].

\section{CT antigen의 분류}

CT antigen은 두 가지로 나뉠 수 있다. 하나는 X chromosome 내에 암호화된 것(CT-X antigens)이고(Table 1) 하나는
X chromosome 내에 암호화 되지 않은 것(non-X CT antigens) 이다(Table 2)[35]. 약 50\%의 CT antigen이 X chromosome에 위치한다. 이들 CT-X gene은 보통 inverted DNA repeats와 관계된 유전자 가족을 형성한다. Human X chromosome의 염기서열에 대한 연구를 통해 X chromosome의 약 $10 \%$ 유전 자가 CT antigen 유전자로 생각되고 있다[30]. 정상 고환에서 CT-X genes은 일반적으로 spermatogonia에서 발현된다[35].

CT antigen 유전자의 발현은 다른 여러 종양에서 다르다. 가장 높은 빈도로 발현되는 암은 방광암, 폐암, 난소암, 간세포 암, 멜라노마가 있다. CT-X gene은 보통 비슷하게 발현되고, 그들을 발현하는 종양은 몇 가지 CT-X antigen를 함께 발현시 키는 경향이 있다. 예를 들면 한 연구에서 유방암의 $40 \%$, 그리 고 멜라노마의 $65 \%$ 가 3 개 이상의 CT-X antigen을 발현하는 것으로 나타났다.

반면, non-X CT antigen에 대한 유전자들은 genome 전체 에 퍼져있고 일반적으로 유전자 가족을 형성하지 않으며 genomic repeats 내에 존재하지 않는다. 고환에서 그들의 발현은 spermatocyte와 같은 germ cell의 분화에서 더욱 두드러져 나 타난다. 고환에서 그들은 spermatogonia와 같이 germ cell의

Table 1. Characteristics of CT-X antigens ${ }^{*}$

\begin{tabular}{|c|c|c|c|c|c|}
\hline $\begin{array}{l}\text { CT antigen gene } \\
\text { family }\end{array}$ & CT identifier & $\begin{array}{l}\text { Number of genes } \\
\text { in family }\end{array}$ & $\begin{array}{c}\text { Chromosome } \\
\text { location }\end{array}$ & $\begin{array}{l}\text { Expression during } \\
\text { germline maturation }\end{array}$ & Function \\
\hline MAGEA & CT1 & 12 & Xq28 & Spermatogonia & Translation co-repressor \\
\hline MAGEB & CT3 & 4 & Xp21-p22 & Migrating PGCs & Unknown \\
\hline GAGE1 & CT4 & 8 & Xp11.4-p11.2 & ND & Unknown \\
\hline SSX & CT5 & 5 & Xp11.23-p11.22 & ND & Unknown \\
\hline NY-ESO-1 & CT6 & 3 & $\mathrm{Xq} 28$ & Spermatogonia & Unknown \\
\hline MAGEC1 & CT7 & 2 & Xq26.Xq27.2 & ND & Unknown \\
\hline MAGEC2 & CT10 & 1 & Xq27 & ND & Unknown \\
\hline CTp11/SPANX & CT11 & 4 & Xq27.1 & Spermatids & Unknown \\
\hline XAGE1/GAGED & CT12 & 8 & Xp11.22-p11.21 & ND & Unknown \\
\hline SAGE1 & CT14 & 1 & Xq26 & ND & Unknown \\
\hline PAGE5 & CT16 & 2 & Xp11.22 & ND & Unknown \\
\hline NA88 & CT18 & 1 & Xp22.12 & ND & Unknown \\
\hline IL13RA1 & CT19 & 1 & Xq24 & ND & Receptor for IL-13 \\
\hline CSAGE & CT24 & 2 & Xq28 & ND & Unknown \\
\hline CAGE & СТ26 & 1 & Xp22.13 & $\begin{array}{l}\text { Spermatids, } \\
\text { Spermatozoa }\end{array}$ & Possible helicase \\
\hline HOM-TES-85 & CT28 & 1 & Xq23 & ND & $\begin{array}{l}\text { Possible transcriptional regulatory } \\
\text { protein }\end{array}$ \\
\hline E2F-like/HCA6611 & СТ30 & 1 & $X q 26.2$ & ND & Transcription factor \\
\hline NY-SAR-35 & СТ37 & 1 & Xq28 & ND & Unknown \\
\hline FTHL17 & СТ38 & 1 & Xp21 & Spermatogonia & $\begin{array}{l}\text { Possible ferritin heavy } \\
\text { polypeptide-like protein }\end{array}$ \\
\hline NXF2 & СТ39 & 1 & Xq22.1 & Spermatogonia & mRNA export to the cytoplasm \\
\hline TAF7L & СТ40 & 1 & Xq22.1 & Spermatogonia & $\begin{array}{l}\text { Possible TATA box binding } \\
\text { protein-associated factor }\end{array}$ \\
\hline FATE1 & CT43 & 1 & Xq28 & ND & Unknown \\
\hline
\end{tabular}

This table is cited from the reference 35 . 
Table 2. Characteristics of non-X CT antigens*

\begin{tabular}{|c|c|c|c|c|c|}
\hline $\begin{array}{l}\text { CT antigen } \\
\text { gene family }\end{array}$ & CT identifier & $\begin{array}{l}\text { Number of } \\
\text { genes in family }\end{array}$ & $\begin{array}{l}\text { Chromosome } \\
\text { location }\end{array}$ & $\begin{array}{l}\text { Expression during } \\
\text { germline maturation }\end{array}$ & Function \\
\hline BAGE & CT2 & 5 & 13 & Spermatogonia & Unknown \\
\hline SCP1 & CT8 & 1 & 1p13-p12 & Spermatocyte & $\begin{array}{l}\text { Structural component of synaptonemal } \\
\text { complexes }\end{array}$ \\
\hline BRDT & СT9 & 1 & $1 \mathrm{p} 22.1$ & ND & $\begin{array}{l}\text { Possible transcriptional regulatory pro- } \\
\text { tein }\end{array}$ \\
\hline HAGE & CT13 & 1 & $6 q 12-q 13$ & ND & ATP-dependent RNA helicase \\
\hline ADAM2 & CT15 & 1 & $8 \mathrm{p} 11.2$ & $\begin{array}{l}\text { Spermatocyte, } \\
\text { spermatids }\end{array}$ & Sperm-egg membrane binding \\
\hline LIP1 & CT17 & 1 & $21 \mathrm{q} 11.2$ & ND & Membrane-associated phospholipase \\
\hline TSP50 & CT20 & 1 & 3p14-p12 & $\begin{array}{l}\text { Spermatocyte, round } \\
\text { spermatids }\end{array}$ & Protease \\
\hline CTAGE1 & CT21 & 2 & 18p11.2 & $\begin{array}{l}\text { Spermatocyte, } \\
\text { spermatids }\end{array}$ & Unknown \\
\hline SPA17 & CT22 & 1 & 11q24.2 & ND & $\begin{array}{l}\text { Binding sperm to the zona pellucida } \\
\text { and other cell-cell adhesion function }\end{array}$ \\
\hline OY-TES-1 & CT23 & 1 & 12p13.31 & Spermatocyte & $\begin{array}{l}\text { Binding sperm to the zona pellucida } \\
\text { and other cell-cell adhesion function }\end{array}$ \\
\hline $\begin{array}{l}\text { DSCR8 (also } \\
\text { known as } \\
\text { MMA1) }\end{array}$ & CT25 & 2 & 21q22.2 & ND & $\begin{array}{l}\text { Binds to proacrosin to mediate pack- } \\
\text { aging and condensation of the acrosin } \\
\text { zymogen in the acrosomal matrix }\end{array}$ \\
\hline BORIS & CT27 & 1 & $20 \mathrm{q} 13.31$ & Spermatogonia & Unknown \\
\hline $\begin{array}{l}\text { AF15q14 (also } \\
\text { known as } \\
\text { D40) }\end{array}$ & CT29 & 1 & $15 q 14$ & ND & $\begin{array}{l}\text { Contains } 11 \text { zinc fingers, possible tran- } \\
\text { scriptional regulatory protein }\end{array}$ \\
\hline PLU-1 & CT31 & 1 & $1 \mathrm{q} 32.1$ & Spermatogonia & Possible suppressor of cell proliferation \\
\hline LDHC & CT32 & 1 & 11p15.5-p15.3 & Spermatocyte & Transcriptional repression \\
\hline MORC & CT33 & 1 & $3 q 13$ & Spermatogonia & $\begin{array}{l}\text { Catalyses the conversion of L-lactate } \\
\text { and NAD to pyruvate and NADH in } \\
\text { the final step of anaerobic glycolysis }\end{array}$ \\
\hline SGY1 & CT34 & 1 & $19 q 13.33$ & ND & Role in signal transduction \\
\hline SPO11 & CT35 & 1 & 20q13.2-q13.2 & Spermatocyte & $\begin{array}{l}\text { Formation of double strand breaks in } \\
\text { paired chromosome homologues }\end{array}$ \\
\hline TPX1 & CT36 & 1 & 6p21-qter & Spermatocyte & $\begin{array}{l}\text { Mediate the binding of spermatogenic } \\
\text { cells to sertoli cells }\end{array}$ \\
\hline TDRD1 & CT41 & 2 & $10 \mathrm{q} 26.11$ & Spermatogonia & RNA binding protein \\
\hline TEX15 & CT42 & 1 & $8 \mathrm{p} 12$ & Spermatogonia & Unknown \\
\hline TPTE & CT44 & 1 & 21p11 & $\begin{array}{l}\text { Secondary spermatocyte } \\
\text { and/or prespermatids }\end{array}$ & PTEN-related tyrosine phosphatase \\
\hline
\end{tabular}

This table is cited from the reference 35 .

분화과정의 후반단계에서 더욱 집중적으로 발현된다. CT antigen의 두 그룹이 각각 spermatogenesis의 다른 단계 동안 발현되기 때문에 그들의 기능은 다를 것으로 예상된다[12].

\section{CT antigens의 면역성}

많은 병리학자들의 연구에서 고환에는 blood-testis barrier 가 존재함을 언급하였다. spermatogenesis는 사춘기에 시작되 고 면역 시스템이 비자기항원으로부터 자기항원을 구별하기 위한 능력이 갖추어질 때 세포 표면에 새로운 antigen이 발현
된다. 따라서 고환의 sperm은 면역 시스템을 자극하지 못한 다. 게다가 antigen-presenting cells은 보통 고환의 interstitial space에 존재하나 이들 세포는 seminiferous tubules에 겨우 존재한다. 그래서 고환은 immune-privilege site로 고려되고 있다. 이 기계적 장벽은 세르톨리 세포들 사이와 모세혈관 내 피세포들 사이의 치밀이음부에 의해 만들어진다. 생식 세포의 표면에서 발현되는 human leukocyte antigen (HLA) class I 발현의 부족은 고환을 immune-privilege site으로 만드는데 매우 중요하다. 이런 여러 가지 이유들로 인하여 CT antigen은 immunotherpy에 대한 target으로 고려되고 있다[4]. 
CT antigens에 대한 체액성 면역반응이 몇몇의 종양에서 보여지고 있다. 예를 들면 췌장암에서는 SCP-1, 유방암에서는 NY-ESO-1, SCP-1, SSX-2, 그리고 전립선, 갑상선, 유방암에서 CTSP-1에 대한 항체가 관찰되었고, 간세포암과 악성 멜라노 마에서 TSGA10에 대한 항체가, 그리고 다발골수종에서 MAGEA3, SSX2, 그리고 NY-ESO-1에 대한 항체 등이 발견되 고 있다. CT antigen은 또한 cytotoxic T lymphocyte에 대해서 도 immunogenicity를 나타내고 있다. 예를 들면 건강한 공혈 자의 말초혈액에서 생성된 Sp17 specific HKA-A1과 B27 restricted cytotoxic T lymphocytes는 HLA가 맞는 골수종 세포 를 죽일 수 있었다[25,38,42].

CT antigens의 체액성과 세포성 반응은 항원 특이적 암 백신의 개발을 직접적으로 이끌 수 있을 것이다. NY-ESO-1 vaccine을 만들기 위하여 34회 이상의 시도가 이뤄졌다. NY-ESO-1 펩티드, 단백질 그리고 pox-NY-ESO-1 백신은 모 두 환자의 강한 NY-ESO-1 체액성 그리고 세포성 반응을 유 도한다. Jonathan Cebon에 의해 시행된 NY-ESO-1 Protein/ISCOMATRIX® 시도는 희망적인 결과를 얻었다. 그리고 제 2상 임상시험이 현재 진행 중이다. 마우스에서 치 료적 효과를 가지는 것으로 고려되는 salmonella/NY-ESO-1 vaccine은 현재 임상 시험을 위해 준비 중이다. 비록 항원 특이적 암백신의 개발이 여전히 초기단계이지만 이것은 미 래에 CT antigen이 면역치료의 중심에 있을 것으로 예상할 수 있다[12].

\section{종양에서 CT antigen 유전자 발현}

다양한 종양 유형에서 CT-X antigen이 발현된다. RT-PCR 분석에 따르면 방광암, 폐암, 난소암, 간세포암과 멜라노마에 서 종종 발현됨을 관찰할 수 있다. 하지만 대조적으로 신장암, 대장암, 위암과 백혈병, 림프종에서는 CT-X antigen의 발현이 드물다. CT-X mRNA는 암세포에서 발현되는 모든 전사체 중 에서 우성으로 나타난다. 예를 들면 microarray에서 폐암을 연구한 결과 20 개의 유전자가 정상 조직과 비교해서 과발현됨 을 알 수 있었다. 그 20 개의 유전자 가운데 6 개가 알려진 CT antigen이었다. 흥미롭게도 과발현된 그 외 유전자들을 분석 한 결과 새로운 CT antigen을 암호화하는 유전자가 나타났다. 이 유전자는 태반과 고환에서 발현되고 뇌를 제외한 다른 모 든 정상 성인 조직에서는 발현되지 않았다[36].

CT-X genes는 종종 공동 발현되고, 그들을 발현하는 종양 은 몇 가지 CT-X antigen을 함께 발현하는 경향이 있다. 유방 암과 멜라노마에서 발현된 9개의 CT-X antigen의 연구에서 유방암과 멜라노마가 각각 $47 \%$ 와 $26 \%$ 가 9 개의 antigen을 발 현하였으며 유방암의 $40 \%$ 그리고 멜라노마의 $65 \%$ 가 3 개 또는 그 이상의 antigen을 발현하였다[31]. 비슷하게 폐암의 연구에 서 9개의 CT-X antigen의 발현에 대하여 연구한 결과 $33 \%$ 는
$\mathrm{CT}$ antigen의 발현이 부족하였고, $10 \%$ 는 하나의 $\mathrm{CT}$ antigen 만이 발현되었고, $57 \%$ 에서 2 개 또는 그 이상, $37 \%$ 에서 3 개 또는 그 이상의 antigen이 발현됨을 확인하였다[37].

CT-X antigen이 양성으로 나타나는 종양에서는 다른 CT-X antigen의 존재와 상관없이 항상 MAGEA3가 발현되었다. 반 면 NY-ESO-1은 MAGEA3가 존재하지 않으면 거의 드물게 발 현되었다. 이 모든 관찰 결과로 볼 때 CT-X antigen의 발현은 상호협동된 유전자 발현 프로그램의 한 부분의 활성화 결과로 인한 것임을 알 수 있다.

CT-X antigen유전자 발현의 유도에서 가장 중요한 인자는 프로모터의 탈메 틸화이다. 프로모터 내 CpG island의 메틸화 는 유전자의 스플라이싱을 위해 필요한 과정이다. DNA 메틸 화와 크로마틴의 재구성의 변화로 Epigenetic reprogramming 이 인간의 두 세대를 거치며 일어난다.

지금까지 모든 CT-X 유전자는 정상 체조직 내에서 메틸화 된 $\mathrm{CpG}$ island를 가지고 있었다. 그리고 그것은 spermatogenesis동안 탈메 틸화에 의해 활성화 되었다. 그것은 실험을 통하여 정상적으로 항원을 발현하지 않는 세포에서도 CT-X 유전자의 프로모터를 탈메틸화 하였을 때 항원이 발현됨을 관찰할 수 있었다. Global DNA hypomethylation, gene-specific hypomethylation, 그리고 regional hypermethylation은 tumorigenesis 동안에 일어나고 종양에서 global hypomethylation은 CT-X 유전자의 발현과 관련이 있다[1].

최근 연구에서는 종양에서 global genome hypomethylation, repetitive DNA hypomethylation 그리고 MAGE 유전자 프로모터의 hypomethylation은 CT-X 유전자 의 발현을 유도하며 서로 관련이 있으나 tumor-suppressor gene의 hypermethylation은 독립적인 것인 것으로 언급하였 다. 하지만 CT-X 유전자의 발현을 위해 hypomethylation 단 한 가지는 충분하지 못하다. 대장암 세포에서 DNA는 전반적 으로 hypomethylation 되어 있지만 CT-X antigen의 발현은 드물게 나타나기 때문이다[10,17].

면역조직화학 분석법을 이용하여 종양에서 발현되는 CT-X antigen을 확인한 결과 그 발현이 균일하게 나타나지 않았다. 그들은 종양 세포들의 각기 작은 부분들에서 발현되었다. 이 현상은 아직 완전히 밝혀지지 않았지만 종양이 줄기 세포와 분화된 세포를 모두 가지는 'quasi-tissue'로서 인식되고 있음 을 보여준다. CT-X antigen은 spermatogonia에서 발현되기 때문에 종양 내에서 줄기 세포와 같은 특징에 대한 표지자로 생각된다. 정상 체조직에서 국소적인 CT-X antigen 발현에 대 한 다른 면역조직화학적 증거가 없다는 것은 정상 체조직 줄 기 세포가 CT antigen을 발현하지 않음을 시사한다.

Non-X CT antigen의 발현에 대한 조절과 한계 등에 대한 정보는 아직 유용하지 않다. non-X CT antigen 자체의 발현 과 CT antigen의 발현과의 관계는 흥미로운 주제가 될 것이 다[35]. 


\section{CT antigen의 기능}

\section{Functions of CT-X antigens}

CT-X antigens은 암백신으로 개발 중이며 임상시험 단계에 있으나 germ line과 종양에서 그들의 생물학적 기능은 여전히 알려지지 않은 상태이다. 그들의 발현은 과연 종양 발생 과정 에 공헌 하는가 또는 세포의 변이 과정에 기능적으로 관련성 이 없는 것인가가 중요한 문제이다. 하지만 그 실마리가 풀리 고 있다. MAGE와 같은 CT antigen의 발현이 인간의 종양발생 에 있어 필수적인 역할을 가지고 있다는 것이 알려진 것이다. CT antigen 중에서 MAGE 유전자 그룹은 25개 이상의 유전자 로 구성되며 MAGE homology domain (MHD)라 불리는 넓은 지역에 존재한다. MHDs에 존재하는 유전자는 Drosophila melanogaster 와 Aspergillus nidulans 같이 다세포성 기관에 존재하지만 Caenorhabditis elegans 또는 단세포성 기관에서 는 찾아볼 수 없다. $\mathrm{MHD}$ 는 다른 알려진 단백질에 대한 어떠 한 homology도 포함하지 않는다. 많은 수의 type II MAGE 단백질(non-CT)에 대한 분석을 통해 이 도메인은 단백질의 상호작용에 중요한 자리임을 알았다. 지금까지 yeast two-hybrid assay를 통해 protein binding partner가 적극적으로 찾던 CT-X 유전자는 MAGEA1이었다. 고환의 cDNA libarary에서 발현된 단백질을 사용하여 MAGEA1에 대한 binding partner 로서 전사 조절체 SKIinteracting protein (SKIP)을 확인하였 다. MAGEA1이 SKIP에 부착하는 것은 MAGE 단백의 카르복 실기 말단에 달려있다. 그 위치는 MAGEA4와 공유되는 도메 인이며 MAGEA4는 또한 SKIP에 부착할 수 있는 것으로 보인 다. SKIP은 DNA binding protein을 다른 단백질에 연결시켜 주어서 전사를 활성화 시키거나 억제시키고, vitamin $\mathrm{D}$, retinoic acid, oestrogens, glucocorticoids, NOTCH1 그리고 transforming growth factor- $\beta$ 등을 포함하는 넓은 범위의 신 호전달 체계에 참여하게 된다[34].

NOTCH1 pathway에서 MAGEA1은 SKIP-mediated NOTCH1 signal transduction을 방해하는 것으로 밝혀졌다. 그러므로 적어도 이 신호전달체계에서 MAGEA1은 전사 억제 자로 작용할 수 있다.

MAGEA1의 germ line에서 기능은 아직 명료히 밝혀지지 않았다. 하지만 SKIP을 통해 활성화 되는 신호전달 체계와 관 련 있다는 것은 분명하다. MAGEA1은 분화 시 필요한 유전자 의 발현을 억제시킨다. 따라서 그것은 spermatogonia에서 발 현되는 것이다. 하지만 마지막 분화 단계에서는 발현되지 않 는다. 암세포에서 세포분화의 억제에 대한 이런 기능은 종양 형성에 중요하게 작용한다.

다른 암 관련 유전자를 이용하여 Yeast two-hybrid 연구를 시행한 결과 2개의 MAGE 단백질이 검출되었다. 그것은 MAGEA11과 MAGEA4이다. MAGEA11은 그것의 internal domain interaction을 조절하여 androgen-receptor 기능을 조
절하는 역할을 한다. 세포질에서 MAGEA11-stabilized ligand-free androgen receptor는 축적된다. 하지만 agonist가 존재할 때 수용체의 amino-terminal ligand-binding domain 의 노출이 증가되고 $\mathrm{SRC} / \mathrm{p} 160$ co-activator를 불러들이게 된 다. 따라서 MAGE는 androgen 신호전달의 이중 증폭 효과를 가진다[2].

MAGEA4는 oncoprotein gankyrin의 binding partner를 찾 는 동안 확인되었다[26]. MAGEA4와 gankyrin 모두 종종 간 세포암에서 과발현 된다. Gankyrin은 retinoblastoma tumor suppressor를 불안정하게 만들고 예정에 없던 cell cycle로 진 입시켜 cell cycle arrest와 apoptosis를 방해한다. MAGEA4는 p53 의존적 그리고 비의존적 세포사멸을 유도하고, MAGEA4 의 카르복실기 말단이 자연적으로 잘려나가면서 생성된 peptide의 활성으로 gankyrin의 oncogenic activity를 저해한다. 이렇게 MAGEA4의 활성이 MAGEA4의 분해 산물에 의존적 이라는 것은 MAGEA4의 또 다른 기능이 존재함을 의미한다. 그것은 MAGEA4의 같은 카르복실기 말단 지역이 SKIP에도 부착할 수 있다는 것이다. 따라서 MAGE 유전자 그룹은 다기 능 조절 분자를 암호화하고 있는 것이다. 이것은 체세포에서 광범위하게 발현되는 MAGE 유전자들의 기능과도 일치한다. 하나의 예를 들면 MAGE family member necdin은 세포 증식 의 강력한 저해자이다. 그것은 신경세포 또는 근육 세포와 같 이 post-mitotic cell에서 현저히 발현된다. Necdin은 MHD를 통해 몇몇의 oncoprotein, tumor-suppressor proteins, the SV40 large antigen, adenovirus E1A, E2F1, E2F4, p53, EFA, heterogeneous nuclear ribonucleoprotein $\mathrm{U}$, 그리고 p75 neutrophin receptor와 상호작용한다. 분자들의 상호작용 중 nec$\operatorname{din}$ 의 범위는 세포 분화를 위한 중요한 전사 인자인 D1x/Msx homeodomain proteins에 까지 넓혀져 있다. Necdin은 먼저 두 MAGE 단백질의 MHD를 통해 다른 MAGE 단백질 (MAGED1)과 상호작용한 후 Msx homeodomain proteins과 상호작용한다. MAGED1은 그 후 D1x/Msx homeodomain 과 직접 상호작용하여 기능적 변화를 이뤄낸다.

최근 연구 결과에서 암세포의 MAGE 유전자의 발현은 malignant phenotype과 치료의 반응에 직접적으로 관여한다는 중요한 결과를 내놓았다. 예를 들면 한 연구에서 tumor-necrosis factor (TNF)에 대한 민감도와 MAGEA1, MAGEA2 또는 MAGEA3의 발현과의 관계에 대하여 넓은 범 위의 human cell lines을 이용하여 실험하였다. 그 결과 3개의 MAGE 유전자 중 적어도 하나를 발현하는 세포계열은 TNF-mediated cytotoxicity에 대한 더 큰 저항성을 나타냈다. 또, ME-180 자궁 경부암 세포에서 MAGEA1가 형질도입 후 안정하게 발현될 때 TNF-mediated cytotoxicity에 대한 민감 도는 줄어든 것으로 나타났다. 다른 연구에서는 MAGEA2 또 는 MAGEA6 유전자의 과발현은 광범위하게 사용되는 항암제 인 PACLITAXEL과 DOXORUBICIN 에 대한 내성을 획득하 
게 될 것이며 MAGE 발현은 malignant phenotype에 관여할 것으로 언급하였다. 약물에 대한 내성은 침습적인 암 phenotype의 대표적인 특징이다. MAGEA2 또는 MAGEA6 유전자 의 형질도입은 세포의 증식을 일으키나 그에 관한 분자 메커 니즘은 알려지지 않았다[9].

MAGE-gene family이 외의 연구 중에서 한 연구는 CT antigen이 malignant transformation의 중요한 인자에 직접 관여 하여 apoptosis를 저해한다고 하였다. 이 연구에서 GAGE family의 구성물인 GEGA7C 또는 GEGA7B는 HeLa cell에 형 질도입되었을 때 interferon- $\gamma$ 또는 FAS (also known as $\mathrm{CD} 95 / \mathrm{APO}-1)$ 를 유도하여 세포사멸에 대한 저항성을 가지게 한다고 하였다.

\section{Functions of non- $X$ CT antigens}

고환에서 non-X CT antigen 유전자들 가운데 몇 몇의 발현 이 감수분열과 동시에 일어난다. 그리고 이들 유전자 산물 중 일부가 이 과정 동안 작용한다. 예를 들면 non-X CT antigen SCP1과 SPO11 genes은 synaptonemal complex의 구성성분 이다. SPO11은 이중가닥 $\mathrm{DNA}$ 를 자르고 감수분열 동안 재조 합이 일어날 수 있도록 한다. 반면 SCP1은 synaptonemal complex의 transverse filament를 만드는 것으로 생각된다. 암 세포에서 non-X CT gene의 발현으로 생성된 단백질과 mitotic-specific protein의 혼합물은 비정상적인 크로모좀의 분 리와 홑배수체를 만들 것으로 예상된다. $\operatorname{COS}$ cells (transformed monkey fibroblasts)에서 SCP-1의 발현은 synaptonemal complexes 형성을 유도한다. 그리고 과발현된 암 세포에서는 감수분열의 불안정성을 증가시킬 수 있다. 불행히 도 COS cells의 핵형은 aneuploid이므로 SCP1이 크로모좀 구 조에 미치는 영향은 판단할 수 없다[29].

Non-X CT antigen 유전자는 다양한 기능을 나타낸다. 예를 들면 PLU-1은 transcriptional co-repressor 이다. 이것은 전사 인자 BF-1과 PAX9와 함께 작용하여 germline의 유전자 발현 을 조절한다. 마우스의 초기 배아발생에서 3 개의 모든 인자가 함께 발현되며 PLU-1와 PAX9는 크로마틴의 구조를 변화시켜 유전자 발현에 영향을 미친다. PLU-1은 pachytene와 diplotene spermatocytes 뿐만 아니라 pre-meiotic spermatogonia에서 가장 높게 발현된다. 아마도 spermatogonia를 감수분 열기에 머무르게 만드는 유전자의 발현을 억제시키는 것으로 생각된다[21]. 또한, PLU-1와 PAX9는 종양에서 과발현되고 악성 유방 세포를 포함하는 림프절에서 과발현된다. 또 다른 non-X CT antigen 유전자 산물인 BRDT은 히스톤의 아세틸화 로 풀려있는 크로마틴을 응집시킨다. 이 과정은 elongating spermatids 단계에서 일어나는 것으로 생각된다. 그리고 마지 막으로, 세포의 표면에서 발현되는 TPX1 와 ADAM2 가 있다. TPX1은 고환에서 세르톨리 세포에 spermatogenic cello이 부착 할 때 필요한 단백질을 암호화 하고 있고, metalloproteinase
$\mathrm{ADAM} 2$ 는 정자와 난자의 막결합에 관여한다.

정상세포와 악성 세포에서 CT-X와 non-X CT antigen유전 자들의 기능에 대한 우리의 지식이 부족하더라도 이미 그들의 생산물은 세포의 신호전달체계, 전사, 번역, 크로모좀의 재조 합 등과 같은 광범위한 과정에 영향을 미치고 있음이 분명하 다[35].

\section{Cancer vaccine trials targeting CT antigens}

CT antigen이 치료적 암백신 표적으로 평가되기 위해서는 다양한 임상실험이 이루어져야 한다. 이들 중 MAGEA3 또는 NY-ESO-1의 peptide-based vaccines과 recombinant protein vaccine에 대한 임상실험이 이루어졌다. 멜라노마 환자에서 두 peptide vaccine은 부분적인 종양의 관해를 유도하였고 경 우에 따라서 완전 관해를 유도하기도 하였다[15,23].

Peptide vaccine과는 달리 recombinant protein vaccine은 환자의 HLA type에 의해 제한되지 않고 광범위한 스펙트럼의 $\mathrm{CD} 8+$ 과 $\mathrm{CD} 4+$ 면역반응을 유도할 것으로 예상된다. 따라서 이것은 더 넓은 범위의 환자들에게 적용할 수 있을 것이다. 처음 MAGE-A3 recombinant protein에 대한 시험으로 GlaxoSmithKline에 의해 만들어진 His-tag MAGE-A3 protein이 제 3 기와 4 기 멜라노마 환자를 대상으로 실험되었다. 실험에 참가한 26 명의 환자 중 5 명의 환자에서 임상적 반응이 나타났다. 그 다음으로 제 2상 임상실험은 182 명의 비소세포 성 폐암환자를 대상으로 이루어졌고, 중간 결과에서 disease-free survival의 개선(hazard ratio $=0.666, p=0.12$ )이 관찰 되었다. 이 결과를 기초로 제 3 상 임상실험이 2270 명의 폐암환 자를 대상으로 진행되고 있다. 추가적으로 immunological adjuvants (AS15 vs. AS02B)를 평가하기 위해 멜라노마 환자에 대하여 MAGE-A3 proteins의 제 2상 임상실험도 시행되었고, 그 결과는 분석 중이다[20].

NY-ESO-1에 대한 첫 번째 recombinant protein vaccine 임 상실험은 멜라노마 환자에서 시행되었다. 종양을 완전히 제거 한 후 His-tagged recombinant proteins을 사용하여 ISCOMATRIX adjuvant의 유무에 따른 시험이 진행되었다. 그 결과는 ISCOMATRIX adjuvant와 함께 NY-ESO-1을 받은 거의 모든 환자에서 anti-NY-ESO-1 antibody 반응이 있었고 광범위한 NY-ESO-1 에피토프에 대한 CD4+ 과 CD8+ T-cell 반응도 함께 유도 되었다.

임상적으로 NY-ESO-1 백신은 멜라노마의 재발의 위험을 줄이는 것으로 확인되었다. 플라시보 또는 NY-ESO-1만 복용 한 환자 23명 가운데 14 명이 재발하였으나 ISCOMATRIX와 함께 NY-ESO-1을 복용한 19명의 환자 중에서는 단지 2명만이 종양의 재발을 보였다. 하지만 제 3 기와 4 기의 멜라노마 환자 를 대상으로 같은 백신을 이용한 최근 연구는 27 명의 환자 가운데 단지 1 명만이 객관적인 반응을 보였고, 이 환자들에게 
서 T-cell 반응은 이전의 minimal residual disease를 가진 환자 그룹에서 나타난 반응보다 더 저하되어 있었다. 이 저하된 T-cell 반응의 이유는 regulatory T-cell에 의한 면역저하 때문 이었다. 그리고 저자는 백신을 이용한 치료는 minimal residual disease 또는 초기 질병에서 종양의 크기가 작고, 면역 저하정도가 최소화 될 때 더욱 유리할 것으로 제안하였다[27].

ISCOMATRIX adjuvants 뿐만 아니라 cholesterol-bearing hydrophobized pullulan (CHP-NY-ESO-1)와 NY-ESO-1가 융 합된 형태 또는 CpG, Montanide ISA-51, imiquimod, 등의 다른 adjuvants를 사용하는 방법과 같이 다른 형태의 NY-ESO-1 protein vaccine constructs가 평가 중에 있다.

또, DNA 백신을 사용하여 in vivo에서 NY-ESO-1 단백질 생산의 가능성이 시험되고 있다. Naked plasmid DNA, vacci$\mathrm{nia} /$ fowlpox viral constructs를 사용하거나 또는 Salmonella typhimurium과 같은 박테리아 벡터를 사용하는 방법이 있다. 대부분의 제 1 상 $/ 2$ 상 임상실험에서 백신의 안전성과 NYESO-1 특이적 면역반응이 유도됨을 보여준다.

항원 특이적 암백신의 가능성을 제외하고서도, NY-ESO-1 는 adoptive immunotherapy에 유용하다. NY-ESO-1 에피토 프에 제한된 HLA-APB1*0401를 표적으로 하는 CD4+ T-cell clones을 멜라노마 환자로부터 분리하여, in vitro에서 증가시 키고 다시 환자에게 주입하였다. 이 환자에서 질병의 완벽한 해소기가 관찰되었고, 치료 후 2년 동안 disease-free 상태가 지속되었다. In vitro 시험에서 이 환자의 adoptive transfer 이 후 이전에 발견되지 않은 anti-MAGE-A3와 anti-Melan A T-cell 반응이 나타났고, 이는 antigen spreading을 의미한다 [14].

최근, NY-ESO-1는 CTLA-4 blockade와 같은 비특이적 면 역치료적 접근과 함께라면 매우 유용할 것으로 밝혀지고 있 다. 이 연구에서 15명의 멜라노마 환자들이 anti-CTLA4 monoclonal antibody (ipilimumab)로 치료하였고, 임상적 이득의 장점의 증거를 가진 8명의 환자 중 5명에게서 NY-ESO- 1 antibody가 양성으로 보였으나, 7명의 아무런 임상적 반응이 없는 환자들의 혈청에서는 NY-ESO-1 antibody가 발견되지 않았 다. 이 결과는 백신치료 후에 anti-NY-ESO-1 면역반응의 유도 와 함께 anti-CTLA-4을 병행한 치료는 시너지 효과를 가지는 것을 의미하며, 이것의 가능성에 대한 연구가 계속 진행되어 야 할 것이다[4,44].

\section{고 찰}

CT antigens은 정상 고환과 여러 다른 종양에서 발현되는 종양 항원의 일종으로 암세포에 대해 특이적으로 발현한다. 이것은 종양 세포의 초기 발견이나 target specific gene-therapy 또는 암의 치료를 위해 사용될 수 있다. 게다가 고환의 immune-privillege와 다양한 암에서 발현되는 testis-specific gene은 암백신의 개발을 위해 유용한 점들이다.

$\mathrm{CT}$ antigen과 그것들의 세포성과 체액성 반응에 대한 연구 는 계속 진행 중에 있으며 그 결과는 환자의 면역치료를 위한 새로운 도구로 사용될 것이다. 종양 세포에서 많은 변화는 $\mathrm{DNA} / \mathrm{RNA}$ 분석에 의해 확인하지 못하는 post-translational modifications에 의한 것이다. 따라서 많은 종류의 종양에 대 한 프로테오믹스 연구가 현재 진행 중에 있다. 이렇게 종양세 포의 단백질 수준에서 $\mathrm{CT}$ antigen의 변화를 확인하고 정상세 포와 비교한다면 암을 위한 새로운 바이오마커를 찾을 수 있 을 것이다. 면역치료는 여전히 임상 전 단계 그리고 임상실험 중에 있으나 가까운 미래에는 임상에서 유용하게 사용될 것으 로 보인다.

\section{감사의 글}

이 논문은 부산대학교 자유 학술과제 2년 지원사업(20092010)에 의하여 연구되었음.

\section{References}

1. Akers, S. N., K. Odunsi, and A. R. Karpf. 2010. Regulation of cancer germline antigen gene expression: implications for cancer immunotherapy. Future Oncol. 6, 717-732.

2. Bai, S., B. He, and E. M. Wilson. 2005. Melanoma antigen gene protein MAGE-11 regulates androgen receptor function by modulating the interdomain interaction. Mol. Cell Biol. 25, 1238-1257.

3. Boel, P., C. Wildmann, M. L. Sensi, R. Brasseur, J. C. Renauld, P. Coulie, T. Boon, and P. van der Bruggen. 1995. BAGE: a new gene encoding an antigen recognized on human melanomas by cytolytic $\mathrm{T}$ lymphocytes. Immunity 2 , 167-175.

4. Caballero, O. L. and Y. T. Chen. 2009. Cancer/testis (CT) antigens: Potential targets for immunotherapy. Cancer Sci. 100, 2014-2021.

5. Chen, Y. T., A. O. Gure, S. Tsang, E. Stockert, E. Jager, A. Knuth, and L. J. Old. 1998. Identification of multiple cancer $/$ testis antigens by allogeneic antibody screening of a melanoma cell line library. Proc. Natl. Acad Sci. USA 95, 6919-6923.

6. Chen, Y. T., M. J. Scanlan, U. Sahin, O. Türeci, A. O. Gure, S. Tsang, B. Williamson, E. Stockert, M. Pfreundschuh, and L. J. Old. 1997. A testicular antigen aberrantly expressed in human cancers detected by autologous antibody screening. Proc. Natl. Acad Sci. USA 94, 1914-1918.

7. Chen, Y. T., M. J. Scanlan, C. A. Venditti, R. Chua, G. Theiler, B. J. Stevenson, C. Iseli, A. O. Gure, T. Vasicek, R. L. Strausberg, C. V. Jongeneel, L. J. Old, and A. J. Simpson. 2005. Identification of cancer/testis antigen genes by massively parallel signature sequencing. Proc. Natl. Acad Sci. USA 102, 7940-7945.

8. Chomez, P., O. De Backer, M. Bertrand, E. De Plaen, T. 
Boon, and S. Lucas. 2001. An overview of the MAGE gene family with the identification of all human members of the family. Cancer Res. 61, 5544-5551.

9. Duan, Z., Y. Duan, D. E. Lamendola, R. Z. Yusuf, R. Naeem, R. T. Penson, and M. V. Seiden. 2003. Overexpression of MAGE/GAGE genes in paclitaxel/doxorubicin-resistant human cancer cell lines. Clin. Cancer Res. 9, 2778-2785.

10. Fratta, E., S. Coral, A. Covre, G. Parisi, F. Colizzi, R. Danielli, H. J. Marie Nicolay, L. Sigalotti, and M. Maio. 2011. The biology of cancer testis antigens: Putative function, regulation and therapeutic potential. Mol. Oncol. 5, 164-182

11. Gaugler, B., B. Van den Eynde, P. van der Bruggen, P. Romero, J. J. Gaforio, E. De Plaen, B. Lethé, F. Brasseur, and T. Boon. 1994. Human gene MAGE-3 codes for an antigen recognized on a melanoma by autologous cytolytic $\mathrm{T}$ lymphocytes. J. Exp. Med 179, 921-930.

12. Ghafouri-Fard, S. and M. H. Modarressi. 2009. Cancer-testis antigens: potential targets for canceri. Arch Iran. Med 12, 395-404

13. Gure, A. O., E. Stockert, K. C. Arden, A. D. Boyer, C. S. Viars, M. J. Scanlan, L. J. Old, and Y. T. Chen. 2000. CT10: a new cancer-testis (CT) antigen homologous to CT7 and the MAGE family, identified by representationaldifference analysis. Int. J. Cancer 85, 726-732.

14. Harada, N., K. Hoshiai, Y. Takahashi, Y. Sakaguchi, T. Kuno, T. shida, and H. Shiku. 2008. Preclinical safety pharmacology study of a novel protein-based cancer vaccine CHP-NY-ESO-1. Kobe J. Med Sci. 54, E23-34.

15. Jäger, E., J. Karbach, S. Gnjatic, A. Neumann, A. Bender, D. Valmori, M. Ayyoub, E. Ritter, G. Ritter, D. Jäger, D. Panicali, E. Hoffman, L. Pan, H. Oettgen, L. J. Old, and A. Knuth. 2006. Recombinant vaccinia / fowlpox NY-ESO-1 vaccines induce both humoral and cellular NY-ESO-1-specific immune responses in cancer patients. Proc. Natl. Acad Sci. USA 103, 14453-14458.

16. Jungbluth, A. A., W. A. Silva Jr, K. Iversen, D. Frosina, B. Zaidi, K. Coplan, S. K. Eastlake-Wade, S. B. Castelli, G. C. Spagnoli, L. J. Old, and M. Vogel. 2007. Expression of cancer-testis (CT) antigens in placenta. Cancer Immun. 7, 15-29.

17. Kaneda, A., T. Tsukamoto, T. Takamura-Enya, N. Watanabe, M. Kaminishi, T. Sugimura, M. Tatematsu, and T. Ushijima. 2004. Frequent hypomethylation in multiple promoter $\mathrm{CpG}$ islands is associated with global hypomethylation, but not with frequent promoter hypermethylation. Cancer Sci. 95, 58-64.

18. Lee, S. Y. 2007. SEREX: discovery of tumor antigens. J. Life Sci. 17, 841-846.

19. Lee, S. Y., Y. Obata, M. Yoshida, E. Stockert, B. Williamson, A. A. Jungbluth, Y. T. Chen, L. J. Old, and M. J. Scanlan. 2003. Immunomic analysis of human sarcoma. Proc. Natl. Acad Sci. USA 100, 2651-2656.

20. Lehmann, F, L. J., S. Gaulis, O. Gruselle, and V. Brichard. 2008. Clinical response to the MAGE-A3 immunotherapeutic in metastatic melanoma patients is associated with a specific gene profile present prior to treatment. XVIth meeting in the cancer research institute international cancer immunotherapy symposium series and the 2008 meeting of the cancer vaccine consortium. New York City. S25.

21. Madsen, B., M. Tarsounas, J. M. Burchell, D. Hall, R. Poulsom, and J. Taylor-Papadimitriou. 2003. PLU-1, a transcriptional repressor and putative testis-cancer antigen, has a specific expression and localisation pattern during meiosis. Chromosoma 112, 124-132.

22. Manning, A. T., J. T. Garvin, R. I. Shahbazi, N. Miller, R. E. McNeill, and M. J. Kerin. 2007. Molecular profiling techniques and bioinformatics in cancer research. Eur. J. Surg. Oncol. 33, 255-265.

23. Marchand, M., N. van Baren, P. Weynants, V. Brichard, B. Dréno, M. H. Tessier, E. Rankin, G. Parmiani, F. Arienti, Y. Humblet, A. Bourlond, R. Vanwijck, D. Liénard, M. Beauduin, P. Y. Dietrich, V. Russo, J. Kerger, G. Masucci, E. Jäger, J. De Greve, J. Atzpodien, F. Brasseur, P. G. Coulie, P. van der Bruggen, and T. Boon. 1999. Tumor regressions observed in patients with metastatic melanoma treated with an antigenic peptide encoded by gene MAGE-3 and presented by HLA-A1. Int. J. Cancer 80, 219-230.

24. Meklat, F., Z. Li, Z. Wang, Y. Zhang, J. Zhang, A. Jewell, and S. H. Lim. 2007. Cancer-testis antigens in haematological malignancies. Br. J. Haematol. 136, 769-776.

25. Mischo, A., B. Kubuschok, K. Ertan, K. Preuss, B. Romeike, E. Regitz, E. Regitz, C. Schormann, D. de Bruijn, A. Wadle, F. Neumann, W. Schmidt, C. Renner, and M. Pfreundschuh. 2006. Prospective study on the expression of cancer testis genes and antibody responses in 100 consecutive patients with primary breast cancer. Int. J. Cancer 118, 696-703.

26. Nagao, T., H. Higashitsuji, K. Nonoguchi, T. Sakurai, S. Dawson, R. J. Mayer, K. Itoh, and J. Fujita. 2003. MAGE-A4 interacts with the liver oncoprotein gankyrin and suppresses its tumorigenic activity. J. Biol. Chem 278, 10668-10674.

27. Nicholaou, T., L. M. Ebert, I. D. Davis, G. A. McArthur, H. Jackson, N. Dimopoulos, B. Tan, E. Maraskovsky, L. Miloradovic, W. Hopkins, L. Pan, R. Venhaus, E. W. Hoffman, W. Chen, and J. Cebon. 2009. Regulatory T-cell-mediated attenuation of T-cell responses to the NY-ESO-1 ISCOMATRIX vaccine inpatients with advanced malignant melanoma. Clin. Cancer Res. 15, 2166-2173.

28. Old, L. J. and Y. T. Chen. 1998. New paths in human cancer serology. J. Exp. Med 187, 1163-1167.

29. Ollinger, R., M. Alsheimer, and R. Benavente. 2005. Mammalian protein SCP1 forms synaptonemal complex-like structures in the absence of meiotic chromosomes. Mol. Biol. Cell 16, 212-217.

30. Ross, M. T., D. V. Grafham, A. J. Coffey, S. Scherer, K. McLay, D. Muzny, and et al. 2005. The DNA sequence of the human $X$ chromosome. Nature 434, 325-337.

31. Sahin, U., O. Türeci, Y. T. Chen, G. Seitz, C. Villena-Heinsen, L. J. Old, and M. Pfreundschuh. 1998. Expression of multiple cancer/testis (CT) antigens in breast cancer and melanoma: basis for polyvalent CT vaccine strategies. Int. J. Cancer 78, 387-389.

32. Sahin, U., O. Tureci, and M. Pfreundschuh. 1997. Serological 
identification of human tumor antigens. Curr. Opin. Immunol. 9, 709-716.

33. Sahin, U., O. Tureci, H. Schmitt, B. Cochlovius, T. Johannes, R. Schmits, F. Stenner, G. Luo, I. Schobert, and M. Pfreundschuh. 1995. Human neoplasms elicit multiple specific immune responses in the autologous host. Proc. Natl. Acad Sci. USA 92, 11810-11813.

34. Scanlan, M. J., A. O. Gure, A. A. Jungbluth, L. J. Old, and Y. T. Chen. 2002. Cancer/testis antigens: an expanding family of targets for cancer immunotherapy. Immunol. Rev. 188, 22-32.

35. Simpson, A. J., O. L. Caballero, A. Jungbluth, Y. T. Chen, and L. J. Old. 2005. Cancer-testis antigens, gametogenesis and cancer. Nat. Rev. Cancer 5, 615-625.

36. Sugita, M., M. Geraci, B. Gao, R. L. Powell, F. R. Hirsch, G. Johnson, R. Lapadat, E. Gabrielson, R. Bremnes, P. A. Bunn, and W. A. Franklin. 2002. Combined use of oligonucleotide and tissue microarrays identifies cancer/testis antigens as biomarkers in lung carcinoma. Cancer Res. 62, 3971-3979.

37. Tajima, K., Y. Obata, H. Tamaki, M. Yoshida, Y. T. Chen, M. J. Scanlan, L. J. Old, H. Kuwano, T. Takahashi, T. Takahashi, and T. Mitsudomi. 2003. Expression of cancer/testis (CT) antigens in lung cancer. Lung Cancer 42, 23-33.

38. Tanaka, R., T. Ono, S. Sato, T. Nakada, F. Koizumi, K. Hasegawa, K. Nakagawa, H. Okumura, T. Yamashita, M. Ohtsuka, K. Asagoe, O. Yamasaki, Y. Noguchi, K. Iwatsuki, and E. Nakayama. 2004. Over-expressin of the testis-specific gene TSGA10 in cancers and its immunogenicity. Microbiol. Immunol. 48, 339-345.
39. Van den Eynde, B., O. Peeters, O. De Backer, B. Gaugler, S. Lucas, and T. Boon. 1995. A new family of genes coding for an antigen recognized by autologous cytolytic T lymphocytes on a human melanoma. J. Exp. Med 182, 689-698.

40. Van der Bruggen, P., C. Traversari, P. Chomez, C. Lurquin, E. De Plaen, B. Van den Eynde, A. Knuth, and T. Boon. 1991. A gene encoding an antigen recognized by cytolytic $\mathrm{T}$ lymphocytes on a human melanoma. Science 254, 1643-1647.

41. Van Pel, A., P. van der Bruggen, P. G. Coulie, V. G. Brichard, B. Lethé, B. van den Eynde, C. Uyttenhove, J. C. Renauld, and T. Boon. 1995. Genes coding for tumour antigens recognized by cytolytic T lymphocytes. Immund. Rev. $145,229-250$.

42. Wadle, A., B. Kubuschok, J. Imig, B. Wuellner, C. Wittig, C. Zwick, A. Mischo, K. Waetzig, B. Romeike, W. Lindemann, M. Schilling, M. Pfreundschuh, and C. Renner. 2006. Serological immune responses to cancer testis antigens in patients with pancreatic cancer. Int. J. Cancer 119, 117-125.

43. Yokoe, T., F. Tanaka, K. Mimori, H. Inoue, T. Ohmachi, M. Kusunoki, and M. Mori. 2008. Efficient identification of a novel cancer/testis antigen for immunotherapy using three-step microarray analysis. Cancer Res. 68, 1074-1082.

44. Yuan, J., S. Gnjatic, H. Li, S. Powel, H. F. Gallardo, E. Ritter, G. Y. Ku, A. A. Jungbluth, N. H. Segal, T. S. Rasalan, G. Manukian, Y. Xu, R. A. Roman, S. L. Terzulli, M. Heywood, E. Pogoriler, G. Ritter, L. J. Old, J. P. Allison, and J. D. Wolchok. 2008. CTLA-4 blockade enhances polyfunctional NYESO-1 specific $T$ cell responses in metastatic melanoma patients with clinical benefit. Proc. Natl. Acad Sci. USA 105, 20410-20415.

\section{초록 : Cancer-testis (CT) 유전자의 고찰 \\ 김미희 ${ }^{1} \cdot$ 송명하 ${ }^{1} \cdot$ 이상률* \\ (부산대학교 의학전문대학원 생화학교실)}

Cancer-testis (CT) antigen은 다양한 종양과 정상 고환에서 제한적으로 발현되고, 암환자에서 체액성 면역과 세포성 면역반응을 일으키는 종양항원이다. 지금까지 MAGE, NY-ESO-1, GAGE, BAGE, LAGE, SSX2, NY-SAR-35를 포함하여 100개 이상의 CT antigen들이 동정되었고, 이러한 CT antigen들은 백신을 이용한 면역치 료에 있어서 중요한 요소로 작용할 것으로 사료된다. CT antigen은 여러 가지 방법들을 통해 확인할 수 있고, X 염색체에 암호화 되어있는 CT-X gene과 X 염색체에 암호화 되어있지 않은 non-X CT gene으로 나눌 수 있다. 또한 몇몇의 종양에서 비정상적으로 활성화되지 않거나 발현되지 않는 CT antigen도 존재한다. 생식세포 조직과 종양에서 CT-X gene의 생물학적 역할이 아직 명확하게 규명되지 않았지만, 현재 여러 종류의 CT antigen을 이용 한 암백신 치료법이 시도되고 있다. 본 논문은 암의 면역치료를 위한 CT antigen의 최근 연구동향과 앞으로의 연구방향에 대해 서술하고자 한다. 